\section{Stupnik M., Kalinichenko V., Rymarchuk B., Pysmennyi 5., Fedko M., Kalinichenko E.}

\title{
IMPROVEMENT OF THE METHOD OF DRILLING AND BLASTING OPERATIONS AT THE USE OF EXPLOSIVE SUBSTANCE «UKRAINITE» IN UNDERGROUND MINING WORKS
}

Об’єктом дослідження є гірський масив залізних руд, якій руйнується за допомогою вибухової речовини, розташованої в глибоких свердловинах. Одним з найбільш проблемних місць є забезпечення рівномірного подрібнення гірського масиву при підземній розробці родовищ корисних копалин на значних глибинах. В Криворізькому залізорудному басейні (м. Кривий Ріг, Україна) на підземних гірничих роботах застосується вибухова речовина «Грамоніт 79/21» українського виробництва, яка надавала змогу отримувати якісне подрібнення рудного масиву до глибини 1200 м. 3 пониженням гірничих робіт ці показники суттєво погіршились, за рахунок проявів гірського тиску, що призводить до переборювання свердловин та підвищених питомих витрат на вибухові роботи.

В ході дослідження використовувався комплексний метод, який базується на аналізі існуючих методів, які впливають на питомі витрати вибухової речовини. За даними практики було встановлено, що при застосовуванні емульсійної вибухової речовини на гірничих роботах питомі витрати вибухової речовини зменшуються, при цьому зменшується собівартість видобутку та поліпшується якість подрібнення масиву. Однак за відсутністю методики розрахунку параметрів буропідривних робіт емульсійну вибухову речовину «Украініт ПП-1» масово не застосовують. Розробка методики з урахуванням характеристик вибухової речовини «Украініт ПП-1» дозволить покращити показники виймання рудної маси.

Показано, що застосування емульсійної вибухової речовини «Украініт ПП-1» призводить до зменшення сумарної довжини свердловин на 35 \%, та зменшення собівартості видобутку. Це пов'язано з тим, що запропонована методика розрахунку має особливість урахування питомих витрат емульсійної вибухової речовини, отриманих дослідн-промисловими випробуваннями, зокрема, коефіцієнта пращездатності емульсійної вибухової речовини.

Завдяки цьому зменшуються витрати на буропідривні роботи та забезпечується можливість отримання розрахункового економічного ефекту від впровадження даної технологї на рівні 0,6 y. о./m. Запропонована схема розбурювання масиву низхідними віялами, у порівнянні з аналогічними відомими, дозволяє зменшити час на буріння свердловин та покращити показники подрібнення гірського масиву без зміни технологї.

ключові слова: лінія найменшого опору, питомі витрати вибухової речовини, діаметр свердловини, коефіцієнт міцності порід, вибухова речовина.

\section{Introduction}

Currently, the underground mining of the Kryvyi Rih iron ore basin (Kryvyi Rih, Ukraine), the extraction of minerals is carried out by traditional development systems using drilling and blasting operations [1,2]. Further development of mineral deposits at greater depths of more than 1260-1350 m leads to an increase in the cost of production due to specific costs: transportation and enrichment of the ore mass; on drilling and blasting [3, 4]. The destruction of the rock massif is carried out by drilling fans of deep wells $35-50 \mathrm{~m}$ long, and their simultaneous detonation with deceleration. For drilling of a mountain massif, НКР-100МПА or КБУ (Ukraine) drilling machines are used, which require considerable time to drill wells in the refining unit. This leads to the destruction of the drilled wells of the total volume according to the practice of $10-15 \%$.

In order to reduce the losses of drilling wells and the undermining of the massif is performed in two or more stages, this leads to an increase in time for the unit and the reduction of labor productivity in the system.

The solution to this problem is possible by reducing the volume of the cleaning unit, the use of self-propelled drilling equipment and more efficient explosives.

Thus, in open-pit mining, high rates are achieved when using an emulsion explosive (EE) «Ukrainite PP-1» (Ukraine). In underground mining, when sinking workings instead of ammonite-6ЖВ EE (Ukraine) is used in the form of «Ukrainite PP-1» cartridges, which makes it possible to reduce the cost of sinking workings and improve the quality of ore grinding.

However, the method of determining the parameters of drilling and blasting operations when used in underground mining works of «Ukrainite PP-1» EE in the massif collapse.

Therefore, the improvement of the existing methodology [5] to determine the parameters of drilling and blasting operations for the emulsion explosive «Ukrainite PP-1» is an actual problem. 


\section{The object of research and its technological audit}

The object of research is a mountain massif, which is destroyed by an explosive located in deep wells. One of the most problematic places is ensuring uniform grinding of the rock massif during underground mining of mineral deposits at great depths.

In underground mining of ore deposits, the following methods of ore blasting are used: drill, borehole, mine or concentrated charges $[6,7]$. There are also other methods of blasting, which are used in the development of coal and polymetallic ores [8,9]:

- underground combines and complexes;

- jackhammers;

- self-crushing ore;

- hydraulic breakage;

- electrophysical methods (high frequency currents, ultrasound, laser);

- nuclear explosions;

- thermal blasting.

Underground mining of a complex structural reservoir of the Kryvyi Rih iron ore basin, systems of surface or subsurface massive collapse of ore and overburden or systems with an open clearing space and subsequent collapse of the pillars are used $[10,11]$. Depending on the mining and geological conditions in the mines, the following breaking systems are used for these development systems, the main of which are: deep well fans, deep well bundles and parallel wells. Also, the blasting can be carried out on the vertical, horizontal and inclined compensation space, as well as on the «clamped medium» $[12,13]$.

At most mining enterprises of the Kryvyi Rih basin, massifs are used by vertical fans of deep wells on a vertical compensation chamber 10-15 m wide, located across the field strike [14, 15]. Under conditions of significant rock pressure in weak unstable rocks, the blasting is carried out on a cutting gap 5-6 $\mathrm{m}$ wide and splitting the floor into two, three sub-floors (Fig. 1).
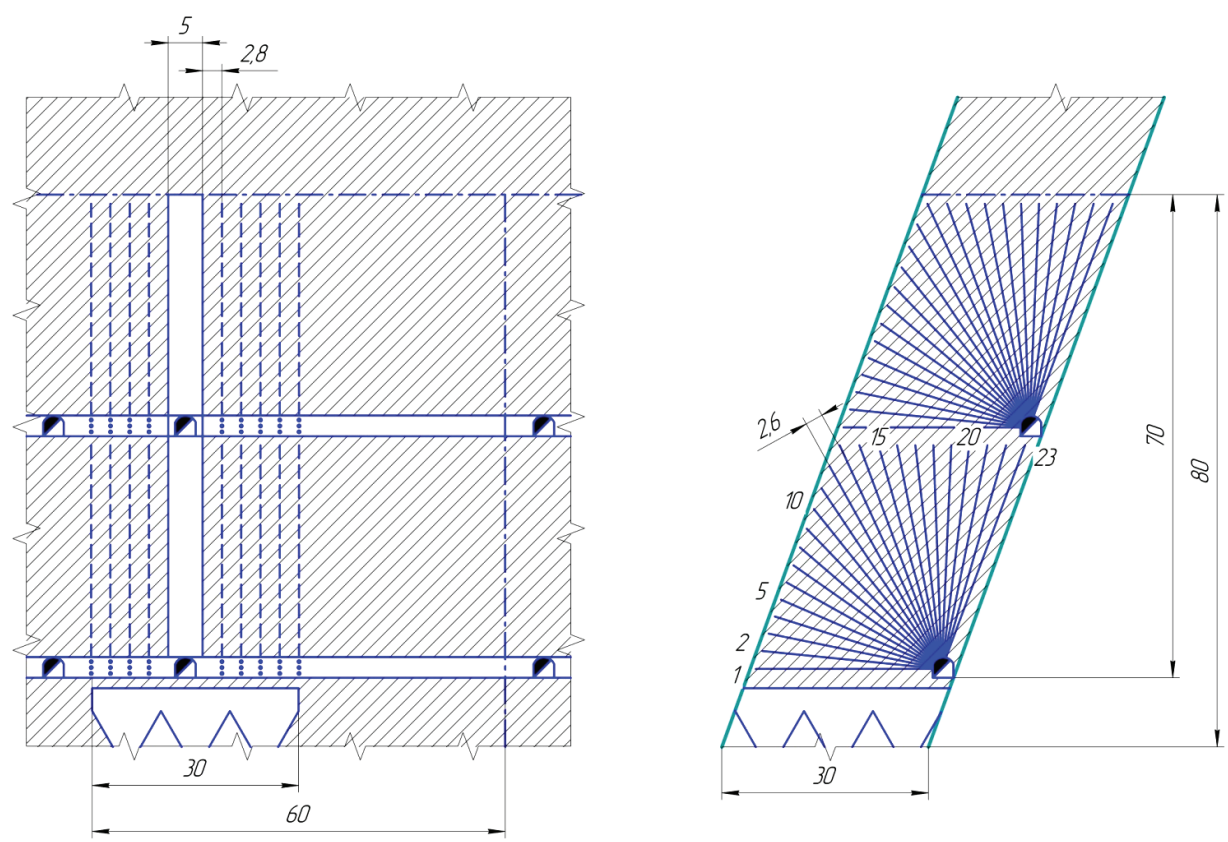

Fig. 1. Scheme of drilling the mountain massif by vertical deep well fans
The method of ore blasting by vertical fans of deep wells to the vertical compensation space has found the widest application (Fig. 1). This blasting scheme in the development of iron ore deposits is used by $40-50 \%$ of the known.

The essence of this option is as follows: a cutting slot is formed in the center of the unit, a drilling drift with a cross-sectional area of $9 \mathrm{~m}^{2}$, from which vertical fans of ascending wells are drilled, lie in the lying side.

The advantages of this option blasting include: a smaller amount of drilling workings; fewer permutations of the НКР-100МПА drilling machine; additional grinding of ore due to collision of pieces of ore during blasting of opposite fans of deep wells.

Disadvantages: uneven crushing of the massif (re-milling ore at the beginning of the wells and increased oversize at the ends of the wells) increases costs of deep wells.

It is possible to reduce the specific costs of deep wells by changing the parameters of the well breakdown, which include:

- well diameter $(d)$;

- the shortest distance from the axis of charge to the exposed surface (least resistance line, $W$ );

- distance between the ends of the wells $(a)$;

- ore outburst from $1 \mathrm{~m}$ well $(\lambda)$;

- specific explosive charge $(q)$, which depend on the

blasting schemes.

At the same time, weighty parameters that affect the quality of breaking are the least resistance line (LRL) and the distance between the ends of deep wells, which depend on the well diameter, the efficiency of the used explosive.

The well diameter can't be changed, since the НКР100МПA drilling machine drills a well only $105 \mathrm{~mm}$. Therefore, the only active factor is the change in the explosive, which has the highest performance at the lowest cost. «Ukrainite PP-1» explosive is included to such explosives

However, the use of the «Ukrainite PP-1» explosive in the collapse of the mountain massif in underground mining operations in the absence of a methodology for determining the parameters of drilling and blasting operations will inevitably lead to a deterioration in the conditions of release and delivery. This, in turn, will not reduce, but increase the cost of mining the ore mass.

The existing method [5], developed for the Grammonite $79 / 21$ explosive, is not suitable for determining parameters when using the Ukrainite PP-1 emulsion explosive, which has other explosive characteristics.

\section{The aim and objectives of research}

The aim of research is improving the methods of drilling and blasting operations by determining the least resistance line when using the «Ukrainite PP-1» explosive substance in underground mining. 
To achieve this aim it is necessary to perform the following objectives:

1. To justify the value of least resistance line in underground mining when using emulsion explosive.

2. To develop a scheme for breaking the mountain massif using the «Ukrainite PP-1» emulsion explosive.

\section{Research of existing solutions of the problem}

The authors of $[16,17]$ make a significant contribution to the development of the theory of destruction of a mountain massif by developing a methodology for determining the parameters of drilling and blasting operations. But the proposed schemes and methods of blasting, charge structures, methods of blasting wells take into account the deterioration of mining and geological conditions with the deepening of underground mining.

In the conditions of the Kryvyi Rih, Zaporizhzhia, Smolyn fields (Ukraine), a well is widely used. There are a large number of borehole blasting schemes, the main of which are: parallel wells, beams of parallel-close wells, fans of deep wells and beams of deep wells. Also, the blasting can be carried out on the vertical, horizontal and inclined compensation space, as well as on the «clamped medium» $[11,18]$.

From the above analysis it is clear that most of the methods for determining the LRL value do not take into account the properties of the explosive or have a large number of coefficients that need to be refined by industrial research [19, 20].

At the Kiruna mine (Sweden), the parameters of drilling and blasting operations are determined and refined in the process of underground mining with industrial explosions of 2-3 fan wells [21, 22]. But the disadvantage of this method is that it is impossible to destroy the cleaning unit by a massive explosion due to the use of end release. Thus, when developing unstable ore bodies, the cost of ore extraction will significantly increase due to additional measures to support mine workings.

An alternative option for mining ore is a development system that is implemented at the Kidd Creek mine ( $\mathrm{Ca}$ nada). This development system after the formation of the camera provides for its bookmarks. This allows to reduce the pressure around the clearing workings, but 2-3 times increases the cost of production, and also requires control over mountain ranges [23, 24].

However, due to the mining and geological and technological features of the underground mining of the Kryvyi Rih iron ore basin, the introduction of high-performance technologies will inevitably lead to a significant increase in production costs.

\section{Methods of research}

There are many methods for calculating the parameters of drilling and blasting operations, which are based on the principle of determining the necessary energy for the destruction of a certain volume of massif with specific physico-mechanical properties.

With known (adopted according to the practice in similar conditions) specific charge of the explosive on the blasting $-q\left(\mathrm{~kg} / \mathrm{m}^{3}\right)$, the least resistance line is determined by the formula $[1,7]$ :

$$
W=d \cdot \sqrt{\frac{7.85 \cdot \Delta \cdot k_{f}}{m \cdot q}}, \mathrm{~m}
$$

where $d$ - the well diameters, m; $\Delta$ - EE loading density of BP, $\mathrm{g} / \mathrm{cm}^{3} ; K_{f}$ - the fill factor of wells by EE (it is taken in the range of $0.75 \ldots 0.95$ with parallel and $0.65 \ldots 0.85$ with a fan pattern); $m$ - the indicator of the convergence of well charges.

In the Gornaya Shoria mines (Russia), the magnitude of the least resistance line with a parallel arrangement of wells is determined by the formula $[8,16]$ :

$$
W=\left(\frac{11 \cdot d \cdot b}{k_{m}}\right) \cdot \sqrt{\frac{3 \cdot a_{s} \cdot H}{f \cdot\left(0.39-0.3 \cdot a_{s}\right)}+1}, \mathrm{~m},
$$

where $b$ - EE relative power factor; $k_{f}$ - the coefficient of the massif fracture $\left(k_{f}>1\right.$ for large unit and $k_{f}<1$ for small unit structure of cracks in the massif); $a_{s}$ - size of the standard piece, $\mathrm{m} ; H$ - the design output of oversize, $\%$.

The Research Mining Institute of the State Higher Educational Institution «Kryvyi Rih National University» (Ukraine) recommends determining the least resistance line, taking into account the blasting direction, type of explosive and its uniform distribution in the massif according to the formula $[13,18]$ :

$$
W=114 \cdot k_{m} \cdot d \cdot \sqrt{\frac{b \cdot \Delta}{f \cdot m \cdot \rho}}, \mathrm{m}
$$

where $k_{m}$ - the coefficient taking into account the blasting direction (when blasting by horizontal and vertical layers and $f<10 k_{m}=1.0$, and when blasting by vertical layers and $f>10 k_{m}=0.9$ ); $\rho$ - the coefficient of uniform distribution of the explosive in the massif.

For the conditions of the Kryvyi Rih iron ore basin, the parameters of drilling and blasting operations are determined by the strength of rocks, using the explosiveness index of the rocks and the reduced charge diameter according to the formula $[5,16]$ :

$$
W_{f}=k_{h} \cdot C_{o} \cdot d_{r}, \mathrm{~m},
$$

where $k_{h}=0.9-1.0-$ massif heterogeneity coefficient; $C_{0}-$ the indicator of rock explosiveness; $D_{r}-$ the reduced well diameter, $m$.

Taking into account the stresses acting in the massif, the magnitude of the least resistance line is determined by the formula [20]:

$$
W_{\sigma}=\frac{W_{f}}{\sqrt[3]{K_{\sigma}}}, \mathrm{m},
$$

where $W_{f}-$ LRL, which is determined by the formula (4); $K_{\mathrm{s}}$ - the coefficient of energy intensity of breaking of strained rocks, equal to the ratio of the specific charge of the explosive, which are set taking into account the depth of mining works and the size of the clearing space $q_{\mathrm{s}}$ to the EE specific charge, which are determined by the strength of the rocks $q_{f}$.

\section{Research results}

After performing the calculations of the least resistance line according to the formula (4), the LRL dependences on 
the well diameter and the coefficient of strength of rocks using M. M. Protodyakonov's scale are constructed (Fig. 2).

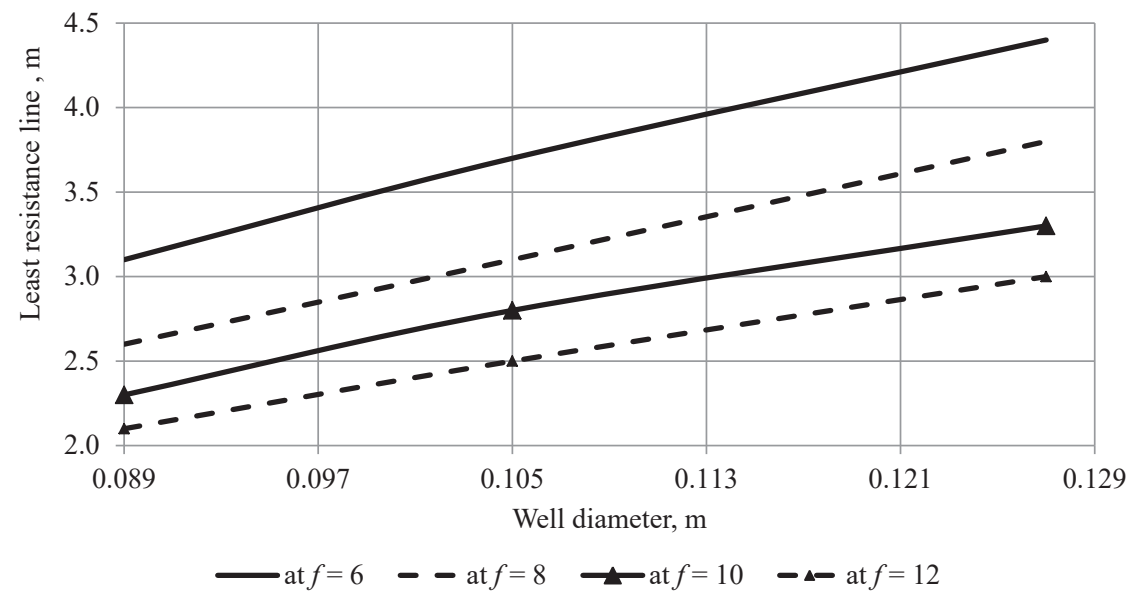

Fig. 2. Dependencies of the least resistance line on the well diameter and the strength factor of the ore according to [5] the well diameter does not significantly affect the specific explosive consumption. At the same time, specific charge increases from 0.5 to $0.8 \mathrm{~kg} / \mathrm{t}$, which is $0.4 \mathrm{~kg} /$ ton less than during blasting in opencast mining, therefore, the method of drilling and blasting [5] requires improvement.

Considering the fact that during the breaking of the ore mass of the «Ukrainite PP-1» emulsion explosive the specific expenditure is much less than with a granulated explosive. Therefore, it is necessary to take into account in the formula (4) the efficiency coefficient of the emulsion explosive, the least resistance line is determined by the expression:

$$
W_{E E}=k_{h} \cdot C_{o} \cdot d_{r} \cdot K_{E E},
$$

where $K_{E E}$ - coefficient of performance of the emulsion explosive.
From the above dependences it is possible to see that with increasing ore strength, the least resistance line decreases, which corresponds to the experience of mining iron ores of the Kryvyi Rih iron ore basin when using the Grammonite-79/21 explosive.

Specific explosive charge is determined by the formula:

$$
q_{f}=\frac{2 \cdot k_{f} \cdot U}{a \cdot W \cdot \gamma}, \mathrm{kg} / \mathrm{t}
$$

where $k_{f}=0.65 \ldots 0.95-$ the fill factor of the wells with an explosive; $U$ - explosive capacity in $1 \mathrm{~m}$ well, kg; $a$ - the distance between the ends of the wells, $\mathrm{m}$; $\mathrm{g}$ - volume weight of ore, $\mathrm{t} / \mathrm{m}^{3}$.

However, increasingly, mining companies with an underground mining method are trying to reduce the cost of ore mining due to various factors. One of such is the introduction into the production of emulsion explosive «Ukrainite PP-1»[19, 25].

This explosive in the implementation in open pit mining shows high performance. Due to the high energy of the explosion, the least resistance line and the distance between the ends of the wells are increased.

Indicators of specific charge from the implementation of the emulsion explosive «Ukrainite PP-1» are shown in Fig. 3.

From Fig. 3, it can be seen that the specific charge of emulsion explosives across enterprises vary from 0.771 to $1.427 \mathrm{~kg} / \mathrm{t}$ and on average amount to 1.008 .

Let's determine the specific charge of explosive according to the formula (6) with a well diameter of $250 \mathrm{~mm}$. The calculation results are shown in Fig. 4. From Fig. 4 it is possible to see that according to the calculation data according to the method of [5],

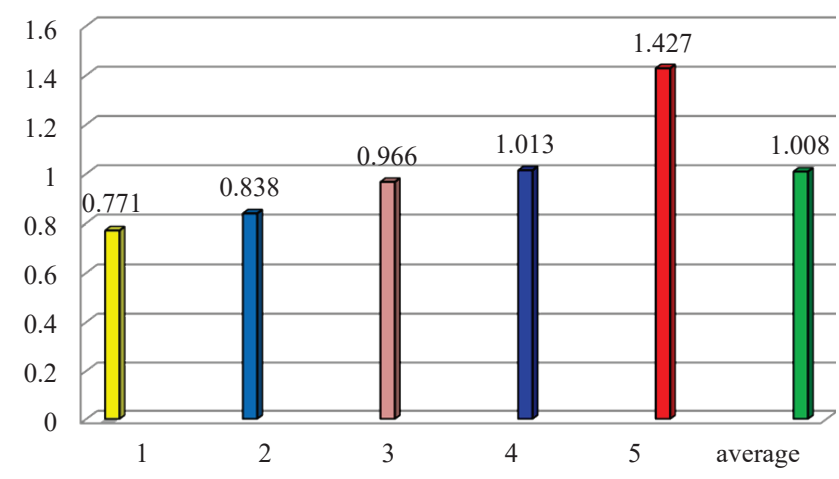

Fig. 3. Average specific charge of the emulsion explosive «Ukrainite PP-1» in enterprises of the Kryvyi Rih (Ukraine) with the open method of mining the Kryvyi Rih iron ore basin: 1 - Private Joint-Stock Company «Central Iron Ore Enrichment Plant»; 2 - Private Joint Stock Company «Southern Mining and Processing Plant»; 3 - Public Joint Stock Company «ArcelorMittal Kryviy Rih»; 4 - Private Joint-Stock Company «Northern Mining and Processing Plant»; 5 - Private Joint Stock Company «Ingulets Mining and Processing Plant»

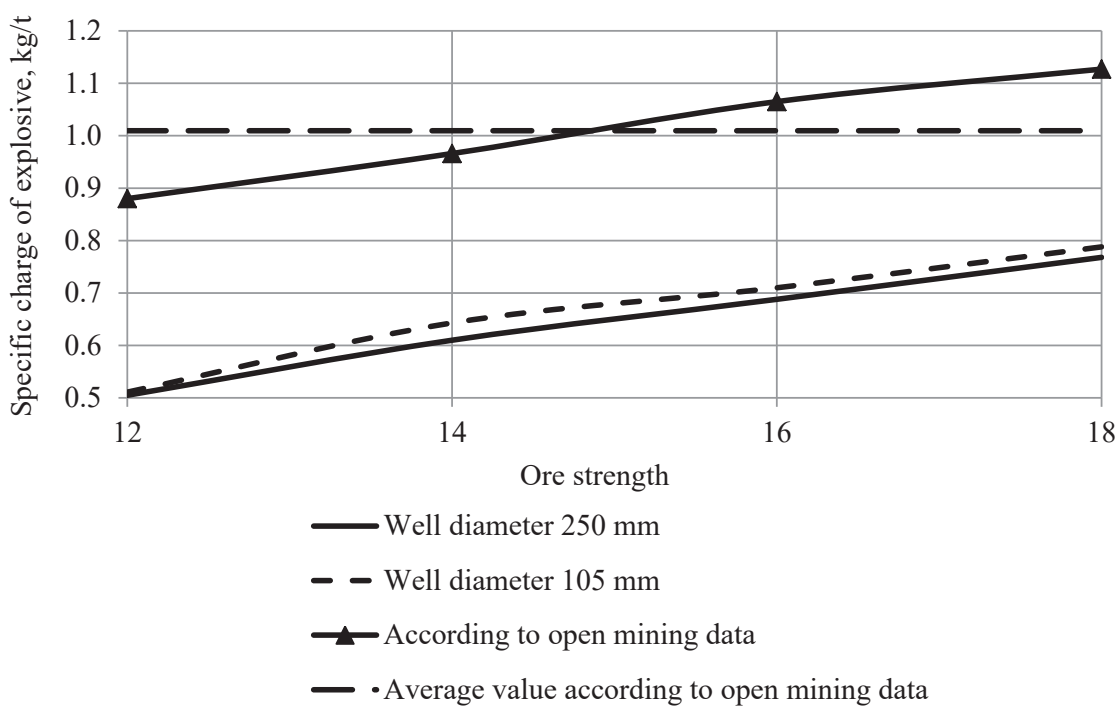

Fig. 4. Dependences of specific explosive charge for blasting on the coefficient of ore strength and well diameter according to the method [5] and according to industrial studies (Fig. 3) 
The coefficient of performance of the emulsion explosive is determined by the formulas:

- at $q_{f}<q_{e e}$ :

$$
\begin{aligned}
& K_{E E}=\exp \left(\frac{0.314 \cdot q_{f}}{q_{E E}}\right), \\
& - \text { at } q_{f}>q_{e e}: \\
& K_{E E}=\exp \left(\frac{0.314 \cdot q_{E E}}{q_{f}}\right),
\end{aligned}
$$

where $q_{f}-$ EE specific charge are determined by the formula (6), $\mathrm{kg} / \mathrm{t} ; q_{E E}$ - the specific charge of explosives, $\mathrm{kg} / \mathrm{t}$ (taken according to the practice of open mining (Fig. 3), or 1.008 is taken.

Having performed the calculations using formula (7), taking into account (8) or (9), the dependences of the least resistance line on the well diameter and the strength coefficient of the ore (Fig. 5) are constructed.

From the graphs shown in Fig. 5, it is possible to see that the value of the least resistance line decreases with increasing rock strength, and increases with increasing well diameter. Comparing the dependencies shown in Fig. 2 and Fig. 5 it can be seen that when using the «Ukrainite PP-1» emulsion explosive, the least resistance line increases by $0.3-0.5 \mathrm{~m}$ with a well diameter of $105 \mathrm{~mm}$.

At the same time, the specific charge of explosives from the well diameter and the strength of the massif using the Protodyakonov's scale, are shown in Fig. 6.

For the conditions of the «Ternivska» mine of the Public Joint Stock Company «Kryvyi Rih Iron Ore Plant» (Ukraine): $L_{b l}-60 \mathrm{~m} ; M_{h}-30 \mathrm{~m} ; \alpha-70^{\circ} ; f_{o}-9-11$ (medium sustainability); $f_{h / b}-12-14$ (medium sustainability); $f_{r / b}-7-9$ (medium sustainability); $\gamma_{o}-3.6 \mathrm{t} / \mathrm{m}^{3} ; F e_{o}-61.4 \%$, $\mathrm{Fe}_{e}-37.5 \%$, calculations of parameters of drilling and blasting operations are performed.
The height of the unit is taken from practical experience $-80 \mathrm{~m}$, in the unit under the floor of $35 \mathrm{~m}$ each. The system for developing the sublevel chamber collapse of ores and country rocks from blasting deep wells to the vertical compensation space is shown in Fig. 7.

The parameters of drilling and blasting operations are calculated using an improved method without taking into account the stress-strain state of the rock massif. According to the characteristics of the massif and the efficiency of the «Ukrainite PP-1» emulsion explosive, the least resistance line is $3.4 \mathrm{~m}$, the distance between the ends of the wells is $3.1 \mathrm{~m}$, and the radii of undercharging around the drill drift are $W=3.4 \mathrm{~m}$ and $1 \cdot 5 \cdot W=5.1 \mathrm{~m}$.

The results of the calculations of drilling and blasting operations when applying the methodology [5] for Grammonite 79/21 and Ukrainite PP-1 explosives and the improved technique for applying the Ukrainite PP-1 emulsion explosive are given in Table 1.

It has been established that when using the «Ukrainite PP-1» emulsion explosive in underground mining operations with the parameters of drilling and blasting operations [5], it will lead to ore over-breaking. This will reduce the productivity of labor on delivery, especially in the flooded units.

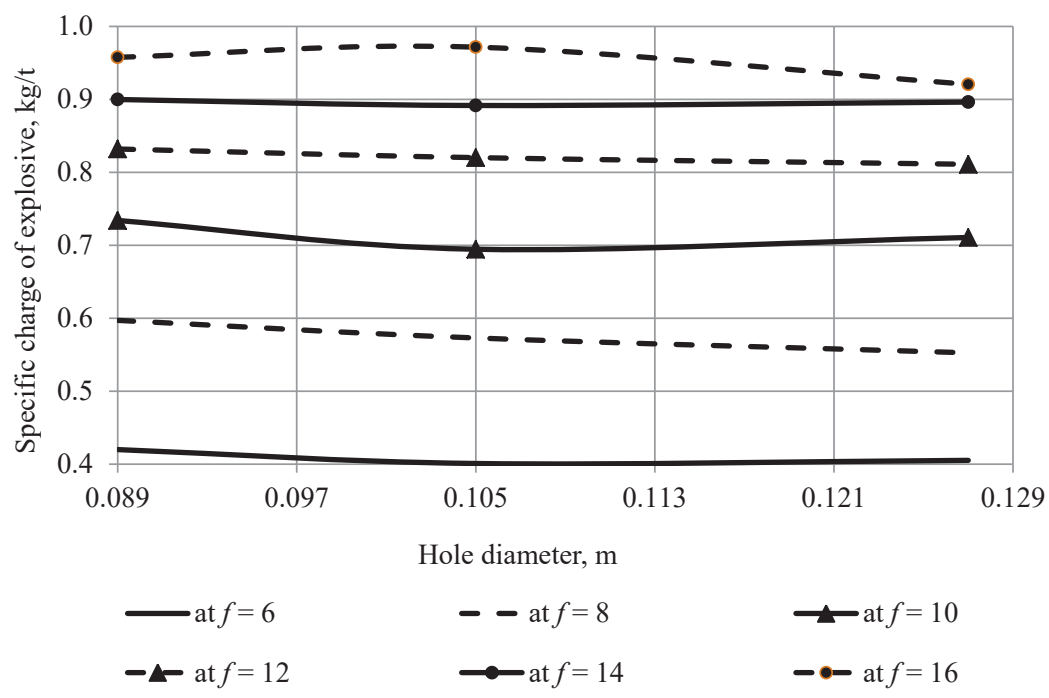

Fig. 6. Dependencies of specific charge of explosive on blasting from the well diameter and the strength coefficient of the ore (according to the improved method)

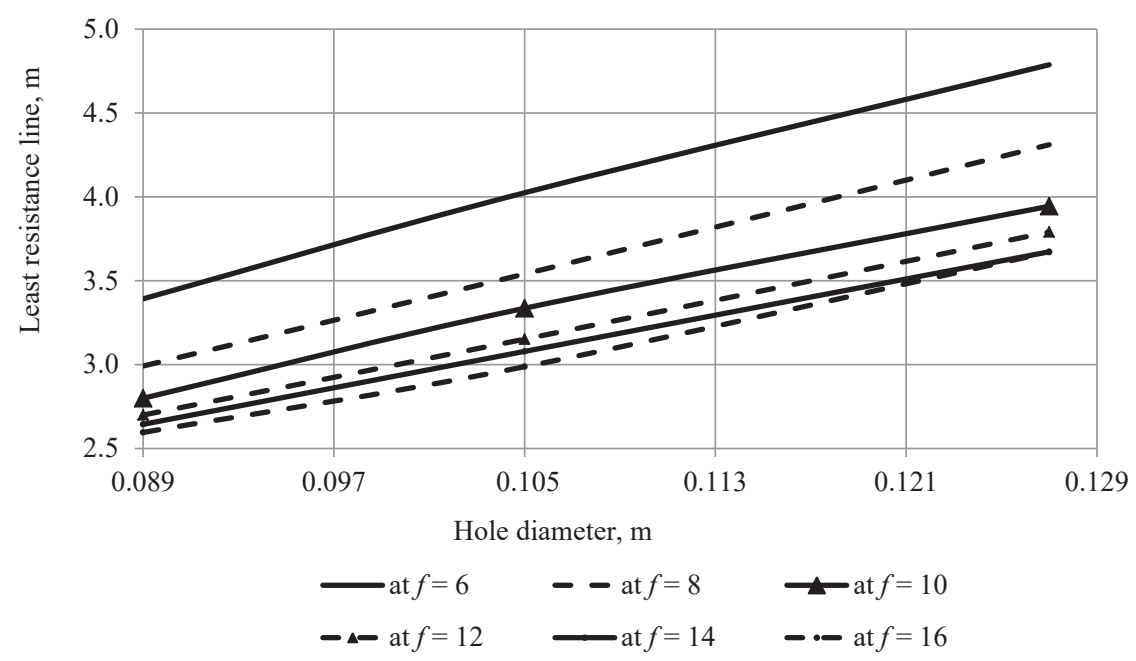

Fig. 5. Dependences of the least resistance line (LRL) on the well diameter and the strength coefficient of the ore (according to an improved method) 


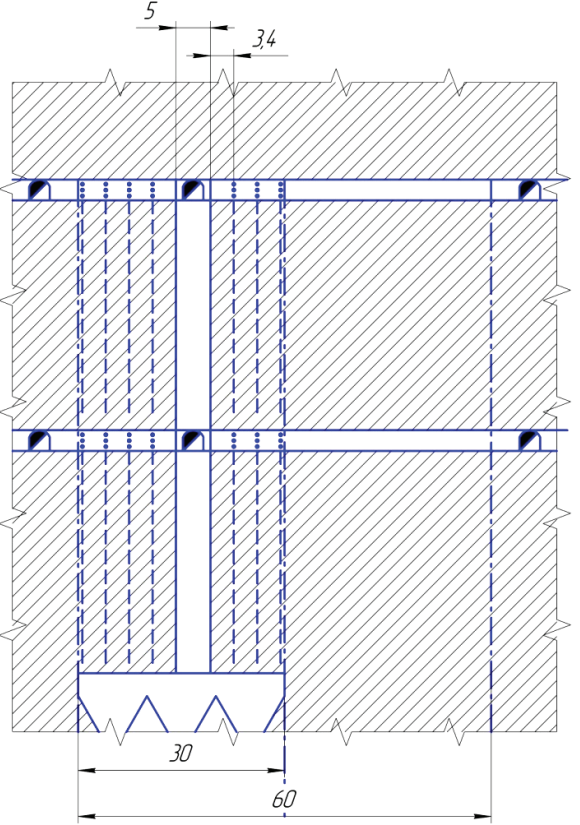

Fig. 7. Diagram of drilling of the massif by descending fans of deep wells with drilling and blasting parameters determined by the improved method

Table 1

Main technical and economic indicators

\begin{tabular}{|c|c|c|c|}
\hline \multirow[b]{2}{*}{ No. } & \multirow[b]{2}{*}{ Indicators } & \multicolumn{2}{|c|}{ Indicators using $\mathrm{EE}$} \\
\hline & & $\begin{array}{c}\text { «Grammonite» 79/21/ } \\
\text { «Ukrainite PP-1»* (Fig. 1) }\end{array}$ & $\begin{array}{l}\text { "Ukrainite PP-1" } \\
\text { (Fig. 7) }\end{array}$ \\
\hline 1 & Balance ore in the unit, $\mathrm{t}$ & 189000 & 189000 \\
\hline 2 & Least resistance line, $m$ & 2.8 & 3.4 \\
\hline 3 & The distance between the ends of the wells, m & 2.6 & 3.1 \\
\hline 4 & Total well length, $\mathrm{m}$ & 11952 & 7639.8 \\
\hline 5 & The total number of explosives, $\mathrm{kg}$ & 76869 & 49409.8 \\
\hline 6 & Ore yield from $1 \mathrm{~m}$ well, $\mathrm{t}$ & 15.8 & 24.7 \\
\hline 7 & Specific charge of explosives, $\mathrm{kg} / \mathrm{t}$ & 0.41 & 0.26 \\
\hline 8 & Specific rate of electric detonators, pieces/thousand tons & 0.54 & 0.35 \\
\hline 9 & Specific rate of detonating cord, $\mathrm{m} / \mathrm{t}$ & 0.14 & 0.09 \\
\hline 10 & Specific rate of blasting wire, $\mathrm{m} / \mathrm{t}$ & 0.011 & 0.011 \\
\hline 11 & The diameter of the middle piece, $m$ & 0.26 & 0.31 \\
\hline 12 & Outburst of oversized fractions, \% & $14.6 / 7.4$ & 15.06 \\
\hline 13 & Labor productivity on blasting, $\mathrm{t} /$ shift & 628.8 & 835.5 \\
\hline 14 & Deep well drilling time & 1261.4 & 806.3 \\
\hline \multirow{3}{*}{15} & \multicolumn{3}{|l|}{ Explosive cost: } \\
\hline & - Grammonite 79/21 & 1808683.2 & - \\
\hline & - Ukrainite PP-1 & 1085209.92 & 697549 \\
\hline 16 & Driller's wages, c. u. & 12614 & 8063 \\
\hline 17 & Wages of a charger and a bomber, c. u. & 2110 & 1356 \\
\hline 18 & Dther materials and equipment, c. u. & $75013 / 76346$ & 81677 \\
\hline 19 & Cost of drilling and blasting, c. u./t & 0.79/0.67 & 0.60 \\
\hline
\end{tabular}

Note: * - when calculating the parameters of drilling and blasting operations according to the method [5] emulsion explosive will be equal as in the case of using the Grammonite 79/21 EE with the same oversize output.

Weaknesses. The use of «Ukrainite $\mathrm{PP}-1 »$ emulsion explosive in underground mining will inevitably lead to the following negative consequences:

- increase in energy consumption and labor resources in the drilling of downhole deep wells with the НКР-100МПА machine;

- increase in labor resources and the number of electric detonators that need to be placed in the wells.

Opportunities. According to the results of the calculations, the approximate economic effect of the use of the «Ukrainite $\mathrm{PP}-1$ » explosive will be 0.12 c. u./t compared to Grammonite $79 / 21$, or $126 \mathrm{c}$. u. in the calculated unit. With an annual mine output of 2.4 million t/year, the annual economic effect will be 203333 c. u.

The estimated specific economic effect from the introduction of an improved method of drilling and blasting operations into production for the «Ukrainite PP-1» explosive will be 0.6 c. $u$. $/ \mathrm{t}$, and the annual 1.44 million c. $u$.

It should be noted that the «Ukrainite PP-1» emulsion explosive compared with Western counterparts is much cheaper with the same technical characteristics.

Threats. When using emulsion explosives in underground mining in highly fractured massifs, there is a possibility of its spreading over cracks, which will lead to oversaturation of the massif with an explosive substance. This will lead to an increase in the cost of ore mining by $5-20 \%$.

\section{SWOT analysis of research results}

Strengths. Improving the methods of drilling and blasting operations by applying the efficiency coefficient of the emulsion explosive will increase the least resistance line and the distance between the ends of the wells. It should be noted that the unit costs of the «Ukrainite PP-1»

\section{Conclusions}

1. As a result of research, it has been established that when using «Ukrainite PP-1» emulsion explosive in underground mining, the least resistance line increases 1.1-1.4 times compared to the Grammonite 79/21 explosive. 
2. A scheme has been developed for breaking the mountain massif into descending fans of deep wells, which makes it possible to use the «Ukrainite $\mathrm{PP}-1 »$ emulsion explosive and obtain a calculated economic effect of $0.6 \mathrm{c}$. u./t.

\section{References}

1. Agoshkov M. I., Borisov S. S., Boyarskiy V. A. Razrabotka rudnykh i nerudnykh mestorozhdeniy: textbook. Moscow: Nedra, 1983. $424 \mathrm{p}$.

2. Stupnik N. I., Pis'mennyy S. V. Perspektivnye tekhnologicheskie varianty dal'neyshey otrabotki zhelezorudnykh mestorozhdeniy sistemami s massovym obrusheniem rudy // Visnik Krivoriz'kogo natsional'nogo universitetu. 2012. Issue 30. P. 3-7.

3. Chernykh A. D., Kolosov V. A., Bryukhovets'kyy O. S. Kompleksna rozrobka rudnykh rodovyshch. Kyiv: Tekhnika, 2005. 376 p.

4. Bondarenko V. I., Kuzmenko A. M., Hryadushchyy Yu. B. Tekhnolohiya pidzemnoyi rozrobky plastovykh rodovyshch korysnykh kopalyn. Dnipro: RVK NHU, 2002. 730 p.

5. Kaplenko Yu. P. Instruktsiya po vyboru parametriv BPR pry otboyke rudy hlybokymy sverdlovynamy. Kryvyy Rih: KHRY, 1977. $28 \mathrm{p}$.

6. Borysenko S. H. Tekhnolohiya pidzemnoyi rozrobky rudnykh rodovyshch. Kyiv: Vyshcha shkola. Holovne vydavnytstvo, 1987. 262 p.

7. Byzov V. F., Korzh V. A. Pidzemni hirnychi roboty. Vol. XII: texbook. Kryvyy Rih: Mineral, 2003. 286 p.

8. Imenitov V. R. Protsesy podzemnykh gornykh rabot pri razrabotke rudnykh mestorozhdeniy. Moscow: Nedra, 1984. 528 p.

9. Osnovnyye raschety sistem razrabotki rudnykh mestorozhdeniy / Malakhov G. M. et. al. Moscow: Nedra, 1968. 273 p.

10. Obhruntuvannya parametriv ochysnoyi kamery parabolichnoyi formy pry vidpratsyuvanni zaliznykh rud v nestiykykh porodakh / Stupnik N. I. et. al. // Hirnychyy visnyk. 2016. Vol. 101. P. 7-12.

11. Stupnik N., Kalinichenko V., Pismennyi S. Pillars sizing at magnetite quartzites room-work // Mining of Mineral Deposite. A Balkema Book, 2013. P. 11-15. doi: http://doi.org/10.1201/ b16354-4

12. Khomenko O. Ye., Kononenko M. N., Zubko S. A. Protsessy pri podzemnoy razrabotke rudnykh mestorozhdeniy. Dnipro: NGU, 2015. 202 p.

13. Chernokur V. R., Shkrebko G. S., Shelegeda V. I. Dobycha rud s podetazhnym obrusheniyem. Moscow: Nedra, 1992. $237 \mathrm{p}$.

14. Stupnik M. I., Pysmennyi S. V. Kombinovani sposoby podal'shoyi rozrobky zalizorudnykh rodovyshch Kryvoriz'koho baseynu // Hirnychyy visnyk. 2012. Vol. 95, Issue 1. P. 3-7.

15. Khomenko O. Ye. Usovershenstvovaniye tekhnologii dobychi zheleznykh rud iz okhrannykh tselikov: monograph. Dnipro: NGU, 2007. 99 p.

16. Byzov V. F., Fedorenko P. Y. Vybukhovi roboty. Vol. X. Biblioteka hirnychoho inzhenera. Kryvyi Rih: Mineral, 2001. 225 p.

17. Andreyev K. K., Belyayev A. F. Teoriya vzryvchatykh veshchestv. Moscow: Oborongiz, 1960. 596 p.

18. Tsarikovskiy V. V., Grigoryev A. P. Perspektivy primeneniya razlichnykh sistem razrabotki pri podzemnoy dobyche rud v Krivbasse // Razrabotka rudnykh mestorozhdeniy. 2004. Issue 85. P. 164-167.

19. Tkachuk K. N., Fedorenko P. I. Vzryvnyye raboty v gornorudnoy promyshlennosti. Kyiv: Vishcha shkola, 1990. 295 p.
20. Kaplenko Yu. P., Kolosov V. A., Shvager N. Yu. Instruktivnometodicheskiye ukazaniya po vyboru parametrov burovzryvnykh rabot (BVR) pri podzemnoy dobyche rud. P. I. Vybor parametrov BVR pri provedenii vyrabotok. Kryvyi Rih: Mineral, 2007. 193 p.

21. Dineva S., Boskovic M. Evolution of seismicity at Kiruna Mine / ed. by Wesseloo J. // Proceedings of the Eighth International Conference on Deep and High Stress Mining. Australian Centre for Geomechanics. Perth, 2017. P. 125-139.

22. Biruk Y. Investigation of Rock-fall and Support Damage Induced by Seismic Motion at Kiirunavaara Mine: Master's thesis. Mwagalanyi Hannington, 2010. P. 74.

23. Development of the method of quasi-optimal robust control for periodic operational processes / Lutsenko I. et. al. // EasternEuropean Journal of Enterprise Technologies. 2017. Vol. 4, Issue 2 (88). P. 52-60. doi: http://doi.org/10.15587/17294061.2017 .107542

24. Development of a method for the accelerated two-stage search for an optimal control trajectory in periodical processes / Lutsenko I. et. al. // Eastern-European Journal of Enterprise Technologies. 2017. Vol. 3, Issue 2 (87). P. 47-55. doi: http:// doi.org/10.15587/1729-4061.2017.103731

25. Udoskonalennya metodyky vyznachennya parametriv burovybukhovykh robit z urakhuvannyam napruzheno-deformovanoho stanu masyvu pry yoho obvalenni na pokhyle oholennya Stupnik M. I. et. al. // Hirnychyy visnyk. 2017. Issue 102. P. $47-53$.

Stupnik Mykola, Doctor of Technical Sciences, Professor, Department of Underground Mining of Mineral Deposits, State Institution of Higher Education «Kryvyi Rih National University», Ukraine, e-mail kpv_p@hotmail.com, ORCID: http://orcid.org/0000-0002-9861-2798

Kalinichenko Vsevolod, Doctor of Technical Sciences, Professor, Department of Underground Mining of Mineral Deposits, State Institution of Higher Education «Kryvyi Rih National University», Ukraine, ORCID: http://orcid.org/0000-0002-1938-2286

Rymarchuk Boris, Doctor of Technical Sciences, Professor, Department of Underground Mining of Mineral Deposits, State Institution of Higher Education «Kryvyi Rih National University», Ukraine, e-mail: rymarchukknu@gmail.com, ORCID: http://orcid.org/00000002-7081-3344

Pysmennyi Serhii, PhD, Associate Professor, Department of Underground Mining of Mineral Deposits, State Institution of Higher Education «Kryvyi Rih National University», Ukraine, e-mail: psvknu@gmail.com, ORCID: http://orcid.org/0000-0001-5384-6972

Fedko Mykhailo, PhD, Associate Professor, Department of Underground Mining of Mineral Deposits, State Institution of Higher Education «Kryvyi Rih National University»,Ukraine, e-mail:fedkomb@i.ua, ORCID: http://orcid.org/0000-0003-4169-7425

Kalinichenko Elena, PhD, Associate Professor, Department of Underground Mining of Mineral Deposits, State Institution of Higher Education «Kryvyi Rih National University», Ukraine, ORCID: http://orcid.org/0000-0002-9138-9271 